Article

\title{
Female Entrepreneurship and Employability in the Digital Era: The Case of Greece
}

\author{
Marios A. Pappas *, Athanasios S. Drigas, Yannis Papagerasimou, Helen Dimitriou, \\ Nadia Katsanou, Sofia Papakonstantinou and Zoi Karabatzaki
}

Institute of Informatics \& Telecommunications, N.C.S.R. “Demokritos”, 15341 Agia Paraskevi, Greece; dr@iit.demokritos.gr (A.S.D.); ypapa@iit.demokritos.gr (Y.P.); lena.dimitriou@yahoo.gr (H.D.); nadia.katsanou@gmail.com (N.K.); spapakon@hotmail.com (S.P.); zkarabatzaki@gmail.com (Z.K.)

* Correspondence: mpap@iit.demokritos.gr; Tel.: +30-2106503230

Received: 12 April 2018; Accepted: 4 May 2018; Published: 8 May 2018

\begin{abstract}
Given the increasing demand of skilled workers in the Information and Communication Technology (ICT) sector during the upcoming years in the European labour market, as well as the digital gap of Greece to the European average, as a result of the ongoing economic crisis, led us to search for innovative ways of dealing with the current situation, following the scientific perspective. Inclusion of an increasing proportion of the Greek population in the ICT sector could result in a reversal of the uncomfortable situation in Greece. The purpose of this study is to investigate the impact of ICT on women's employability and entrepreneurship, as well as on career prospects in managerial positions in Greece, in order to map the existing situation, identify needs, and suggest training routes. Data from 1035 women were collected, via questionnaires and interviews, regarding ICT skills' benefits on female employability and entrepreneurship. As revealed by the findings, although women believe that ICT skills are among the most crucial factors of success in the 21st century, however, they state that they feel underrepresented in the digital era.
\end{abstract}

Keywords: digital entrepreneurship; ICT skills; female employability; digital era

\section{Introduction}

The direction of the international economy to entrepreneurship contributed to the increasing interest of women to entrepreneurship. In general terms, women entrepreneurs are a minority compared to men, however, there are significant differences across countries [1,2]. For this reason, initiating an enterprise requires extra effort for women in a male-dominated environment [3]. Gender-based barriers to entrepreneurship may negatively affect a country's competitiveness and productivity [4]. Women represent one third of the graduates, specializing in science and technology in Europe [5]. In terms of entrepreneurship, more than half of the European entrepreneurs in non-ICT service sectors are women, while only $19.2 \%$ of European entrepreneurs in the ICT sector, are women. Women-owned technology firms are smaller than those that are male-owned, however, female entrepreneurs seem to be more optimistic about the future and less profit-driven [6].

Based to the results of the European project Women Entrepreneurs in Europe, it was revealed that, in 2012, around 30\% of all entrepreneurs in Greece were female in comparison to 31\% in the EU-28 [7]. Most of these women were solo entrepreneurs. Based on data from European countries, men are much more likely to deal with enterprises than women [8]. The socio-cultural status of women and the lack of access to networks of information, as well as to capital, are considered as barriers against female entrepreneurship [9]. There is evidence that higher education, as well as support by family and friends, could enhance women to start their own business [10]. In middle income and developing countries, the gender gap in entrepreneurship is more evident [11]. 
The majority of female entrepreneurs in Greece are full-time. In 2012, about 11\% of Greek female entrepreneurs worked part-time in their business, a percentage which was significantly lower compared to the European average (30\%). Thus, since 2008, the number of women entrepreneurs in Greece has declined by $5 \%$, while the number of men entrepreneurs decreased by $13 \%$. The EU average of female entrepreneurs surged by $2 \%$ and the European average for men declined by $1 \%$. The number of women employing staff decreased by $16 \%$ in Greece, while the number of male entrepreneurs with staff decreased by $34 \%$.

In addition, in terms of employability, there is an overwhelming disadvantage that women face on pay issues, as well as in career progression [12]. A large number of factors, such as educational level, natural or physical factors, and stereotypes, are responsible for gender issues in the area of employability [13]. For their personal development, women should overcome a variety of obstacles and continuously enrich their qualifications by acquiring new skills and applying innovative practices [14].

Capitalist society of our century is transformed to a knowledge-based society [15]. According to the Open Innovation approach, firms should utilize not only their own technologies, but also external know-how, ideas, and technologies [16,17]. Information and communication technologies (ICT) have gained significant penetration in all sectors of economic activity, being the most necessary tools for the rapid economic growth of an economy. At the same time, they allow the creation of new working models in the integration of larger social groups. Not only new jobs are created based on these technologies but, at the same time, existing jobs adapt to these technologies, resulting the transformation of the traditional economy. Information and communication technologies (ICT), such as the Internet, grids, and cloud computing, could be used for the restructuring of traditional practices in the digital era [18-20].

Most entrepreneurs use ICT tools for the optimization of production, marketing and strategic objectives. ICT innovation seems to be a key factor for success in entrepreneurship [21]. Despite the barriers for female entrepreneurship, ICT could become efficient tools for women, in order to have equal opportunities with men in business development.

Technological process during the last decades has reformed entrepreneurial environment in Greece. Therefore, factors affecting entrepreneurial skills and knowledge transmission have also been reformed [22]. Female entrepreneurship in Greece acquires interest, due to the ongoing economic crisis [23]. Despite the fact that European Commission encourages member-countries to carry out research targeted to female entrepreneurship, in Greece this kind of research remains limited [24]. In addition, Greeks maintain low performance in ICT skills, as Greece ranks 26th in the Digital Economy and Society Index (2017). It is noted that the low level of digital skills in Greece can act as a barrier to the further improvement of the digital economy and society [25].

The purpose of this study is to define the current situation regarding the involvement and awareness of women and especially young ones in ICT, as well as the benefits issuing from their use in terms of entrepreneurship and employment. This study will target on investigating how social networks and the Internet can combat inequalities in employment and create new opportunities for entrepreneurship and self-employment to women. In addition, we are going to investigate the awareness level of Greek women about the employment opportunities offered by the internet, social networks and new technologies, with an emphasis on social aspects. The potential contribution of the study will be to highlight the impact of ICT on the creation of new employability and entrepreneurship paths in the Greek labour market.

\section{Materials and Methods}

\subsection{Design}

This study examines the trends in the employability of women in the digital era, reviewing literature data, as well as survey findings, to identify possible skills mismatches, and suggest training requirements to meet the demands of the future. 
This study addresses the following research questions:

What are the current trends in employability of women in the Greek digital era and what are the different types of skills required?

What are the current trends in entrepreneurship of women in the digital era and which are considered as the most important entrepreneurial skills in Greece?

What are the barriers in the accomplishment of these skills?

What are the observed gaps in skills and how these gaps can be bridged through education and training in Greece?

Specifically, this paper refers to the analysis and presentation of the general findings of the social research results (field research via an online survey that conducted in Greece during June-September 2016, focus group research in 11 October 2016 and personal Interviews with key stakeholders between 17-31 October 2016), as well as a correlation of the desk research with the findings of the surveys.

\subsection{Procedure}

The methodology employed has been structured into three phases:

Phase 1. Research and documentation reviews of reports, journal articles, and statistical data to provide an overview of the trends in employability in the digital economy and on the demand for skills.

Phase 2. Collection of information leading to a mapping of the situation, identification of needs, and the description of any known best practice scenarios. The data collection methods included survey data conducted in Greece during June-September 2016 through online questionnaires, focus groups, and interviews with stakeholders to test the survey and literature review findings on women's employability, career prospects in managerial positions, female entrepreneurship, STEM education, and digital skills, the barriers that contribute to skills gaps and limit work prospects, and how skill demands can be met by education and training.

Phase 3. An analysis of the needs as identified in Phase 2. These needs were classified and prioritized according to their importance and relevance, leading to proposals for tools to help meet the needs of the target group.

\subsection{Measures}

The methodology used in this study involved:

An extensive literature review from multiple sources of qualitative and quantitative information (reports, journal articles, statistical data) to provide an overview of the trends in employability in the digital economy and on the demand for skills. For the literature review, online search engines and electronic databases were used (Google Scholar, Science Direct, IEEE Xplore, dblp and Elsevier Scopus) in order to collect data from published works of the last two decades.

Analysis of survey data conducted in Greece during June-September 2016.

Interviews with stakeholders and focus group, to test the survey and literature review findings on women's employability, career prospects in managerial positions, female entrepreneurship, STEM education and digital skills, the barriers that contribute to skills gaps and limit work prospects, and how skill demands can be met by education and training.

Both the questionnaire and interviews targeted to measure women's attitudes towards female entrepreneurship/employability in the ICT sector, gender-based differences in the ICT sector, and the importance of e-skills (dependent variables), in terms of their age, level of education, marital status, and employment status (independent variables).

\subsubsection{Questionnaire}

For the purpose of this study, a random sample was used, including women, aged 16 and older, who had at least basic computer skills, as the questionnaire was circulated and filled electronically. 
The questionnaire was designed on an electronic questionnaires platform and the link was massively sent via e-mail, or posted in social media. In particular, the questionnaire consisted of 36 questions, based on five thematic units:

1. Information on the profile of the respondent

2. Women's entrepreneurship in the ICT sector

3. Employability of women in the ICT sector

4. Attitudes regarding gender-based differences in the ICT sector

5. Importance of e-skills and further training skills

Regarding the type of questions, there were 21 radio-button questions, nine text-box, five check-boxes, and one dropdown-menu question. For the analysis of data, IBM's SPSS Statistics Subscription (Armonk, New York, NY, USA) was used. For the final version of the questionnaire, a pilot test was conducted in a sample of 19 private and public sector female workers, unemployed, and female students.

\subsubsection{Interviews}

For the purpose of our research, the method of direct, in-depth, structured interview was also used. Through personal interviews with policymakers, private and public sector executives, as well as entrepreneurs and mentors/consultants, the qualitative method was used, as it was considered more appropriate in order to gather targeted and in-depth information and data. There were 35 interviews, based on structural questions, which aim at gathering factual material with key persons of the economy, entrepreneurship, education, self-government, and policy-makers, regarding the required skills of 21st century, as well as their viewpoints on the position of women in the ICT sector. All participants were informed on the focus group objectives, the methods of exploitation of the results of the interviews, the focus group implementation process, the benefits and the risks, as well as the level of confidentially. Interviews were structured under the following topics:

1. European Union and skills

2. Essential skills

3. Skills and stereotypes

4. Skills and women entrepreneurship-employment

5. STEM skills and women

Starting with the desk research helped us suggest what to focus on during the interviews and, thus, prepare a set of common questions for all interviewees. The next phase started with thinking about the categories and forming the questions and their specific order. Structured interviews supported data analysis, as different answers were given to the same questions.

\subsection{Sample and Characteristics}

Data from 1000 valid questionnaires from all the geographic departments of Greece were included in the statistical analysis. A total of $93.8 \%$ of the women surveyed were higher education graduates and $5.9 \%$ were secondary education graduates. A total of $42.2 \%$ of the higher education graduates have a master's degree and $5.2 \%$ a PhD (Table 1). The ages of the women surveyed were mostly between $16-44$ years (93.6\%). A total of $39.5 \%$ of these were aged from 16 to 24 years, $31.0 \%$ were between 25 and 34, and 23.1\% were between 34 and44 (Table 2). Regarding the marital status of women who participated in the survey, $47.2 \%$ are single, $42.5 \%$ married, and $8.8 \%$ divorced or separated (Table 3). Finally, Table 4 shows the professional status of women who participated in the survey. As shown, $61.5 \%$ of women are employed, $19.8 \%$ are unemployed, $12.1 \%$ are self-employed, and $4.9 \%$ are students. 
Table 1. Education.

\begin{tabular}{ccccc}
\hline & Frequency & Percentage & Valid & Cumulative Percentage \\
\hline Secondary school & 2 & 0.2 & 0.2 & 0.2 \\
High School (Lyceum) & 57 & 5.7 & 5.7 & 5.9 \\
Technological education & 51 & 5.1 & 5.1 & 11.1 \\
Higher education & 413 & 41.3 & 41.5 & 52.6 \\
Master's degree & 420 & 42.0 & 42.2 & 94.8 \\
PhD & 52 & 5.2 & 5.2 & 100.0 \\
Subtotal & 995 & 99.5 & 100.0 & \\
NA & 5 & 0.5 & & \\
Grand total & 1000 & 100.0 & & \\
\hline
\end{tabular}

Table 2. Age.

\begin{tabular}{ccccc}
\hline Age & Frequency & Percentage & Valid & Cumulative Percentage \\
\hline $16-24$ & 394 & 39.4 & 39.5 & 39.5 \\
$25-34$ & 309 & 30.9 & 31.0 & 70.5 \\
$35-44$ & 230 & 23.0 & 23.1 & 93.6 \\
$45-54$ & 62 & 6.2 & 6.2 & 99.8 \\
$55+$ & 2 & 0.2 & 0.2 & 100.0 \\
Subtotal & 997 & 99.7 & 100.0 & \\
NA & 3 & 0.3 & & \\
Grand total & 1000 & 100.0 & & \\
\hline
\end{tabular}

Table 3. Marital Status.

\begin{tabular}{ccccc}
\hline Marital Status & Frequency & Percentage & Valid & Cumulative Percentage \\
\hline Never been & 472 & 47.2 & 47.2 & 47.2 \\
married & 425 & 42.5 & 42.5 & 89.8 \\
Married & 14 & 1.4 & 1.4 & 91.2 \\
Widowed & 15 & 1.5 & 1.5 & 92.7 \\
Separated & 73 & 7.3 & 7.3 & 100.0 \\
Divorced & 999 & 99.9 & 100.0 & \\
Sub total & 1 & 0.1 & & \\
NA & 1000 & 100.0 & & \\
Grand total & & &
\end{tabular}

Table 4. Professional status.

\begin{tabular}{ccccc}
\hline & Frequency & Percentage & Valid & Cumulative Percentage \\
\hline Employed & 615 & 61.5 & 61.5 & 61.5 \\
Self-employed/Entrepreneur & 121 & 12.1 & 12.1 & 73.6 \\
Unemployed & 198 & 19.8 & 19.8 & 93.4 \\
Student & 49 & 4.9 & 4.9 & 98.3 \\
Other & 17 & 1.7 & 1.7 & 100.0 \\
Total & 1000 & 100.0 & 100.0 & \\
\hline
\end{tabular}

At the stage of completion of the analysis of the data obtained from the questionnaire survey, a focus group was implemented in order to discuss and further refine the results obtained from the analysis of the survey responses. This method is an important qualitative data mining tool through direct interaction of the participants. The focus group was set up taking into account the full range of stakeholders and included 35 women with similar socioeconomic characteristics, representatives from policy bodies, the academic community, enterprises, and mentors' entrepreneurship.

\section{Findings}

\subsection{Findings from the Desk Research}

\subsubsection{Digital Gender Gap}

Women's under-representation in the information and communication sector, despite the existence of encouraging initiatives, is due to wider structural inequalities [26]. It seems that because of the 
prevailing cultural norms and practices, the ICT industry constitutes an unpleasant environment for females. Females find it difficult to integrate in a work environment that important issues concerning the company or professional advancement can be decided in an informal setting outside the office, such as a sporting event [27], and because there are often practices overtly patronizing to women and making unflattering comments on their skills [28]. In addition, in many companies it is required for employees to be willing to work long hours in order to finish an ongoing project, thus requiring women to put work ahead of family commitments. Companies may hesitate to hire women for demanding IT positions, because of the fear that family obligations will reduce their productivity [29]. Additionally, although there is evidence in the literature of passionate female professionals who enjoy their work and are willing to put their personal lives in second place, there is also evidence of professionals who, although they love their work, they would also like a more balanced work and family life [30]. Focus group participants also consider family-career compromise as one of the most prominent discriminating factors against women.

There seems to be an unattractive portrayal of the ICT industry, in which computer experts live in a lonely, antisocial, and inactive world preventing women from engaging in this profession. In order to explain why gender inequality exists in ICT workplaces, some researchers highlight the nature of power dynamics in work contexts and their significance for understanding and explaining employees' experiences [31]. In conclusion, although gender is an easy classification framework to apply, research also indicates that women are dissimilar in their responses to workplace disabling effects and caution should be exercised in the interpretation of data [32].

There are many studies revealing that men are more familiar to new technologies compared to women [33,34]. A Greek study with 165 participants revealed that male freshman students are more willing to use computers in their everyday life, compared to females [35]. However, there are studies stating that women seem to realize the importance of ICT skills, as well as that they are able to learn programming or other computer skills. There is also evidence that women on computer courses perform as well as their male counter parts and, in some cases, better than males [36]. However, women seem to be less confident and more anxious compared to men when they deal with new technologies [37]. It seems that engaging with new technologies, as well as training on Internet self-efficacy, could significantly improve attitudes toward computers, for both women and men [38].

\subsubsection{Gender Gap in STEM}

A situation that is still maintained nowadays, is the mismatch between men and women in science, technology, engineering, and mathematics (STEM). In Greece, and according to Programme for International Student Assessment [39] results, boys seem to perform better than girls in science, which is consistent with the results in most Organisations for Economic Cooperation and Development (OECD) countries. The interpretations of how the gender gap evolved vary, including background characteristics and structural barriers in $\mathrm{K}-12$ education, as well as family viewpoints or psychological factors [40].

Recent studies also suggest that women's interest in STEM is affected by a perceived mismatch between STEM careers and communal values [41]. Girls may also show less interest in mathematics than boys because they feel less talented at it, given the prevalent stereotype [42] that is reflected in men's and women's assessments of their own abilities. However, the most recent meta-analyses revealed no gender difference in U.S. students' standardized test scores [43]. Gender differences in spatial thinking skills and especially in mental rotation, beginning in early childhood, could contribute to the STEM gender gap [44]. There seems to exist an array of social and personal factors that affect women motivation in STEM. In attempt to close the gender gap in STEM, Krämer et al. (2016) showed with their study that presence of a virtual agent (instructor) could enhance female performance, effort, and motivation in mathematics [45]. 


\subsubsection{Bridging the Gap}

e-learning, as an Internet-enabled learning process delivered anytime, anywhere, offers valuable opportunities to education and training. Previous studies show that perceptions about the usefulness of technology and e-learning are significantly correlated with gender [46].

Many studies confirm that male students seem more positive than their female classmates, to engage with e-learning [47]. However, there are studies indicating that women would accept the use of ICT more than men [48]. Computer skills, age, gender and different learning styles, could affect students' attitudes towar5ds e-learning. However, there is evidence that the gender gap in these attitudes is narrowing [49,50]. Training organizations should apply the e-learning format as the students independently from their gender are interested in the various forms of e-learning [51].

E-mentoring from experienced experts, who teach and counsel beginners into the ICT sector, could also enhance bridging the gap [52].

Except of development of specific skills, e-mentoring could contribute so that mentees gain inspiration and psychological advantage for their career and personal improvement [53].

\subsection{Findings from the Questionnaire Survey}

\subsubsection{Women's Employability in ICT Sector and Employability Skills}

A set of questions in the questionnaire aimed at investigating the use of ICT in Greece by women and girls in terms of employability. Table 5 lists the responses of women surveyed in relation to gender segmentation in ICT skills. As we can see, while $56.2 \%$ think that there is no difference, and $38.6 \%$ think that men possess greater ICT skills.

Table 5. Gender and segmentation in ICT skills.

\begin{tabular}{ccccc}
\hline & Frequency & Percentage & Valid & Cumulative Percentage \\
\hline Women & 50 & 5.0 & 5.0 & 5.0 \\
Men & 386 & 38.6 & 38.7 & 43.7 \\
Equally & 562 & 56.2 & 56.3 & 100.0 \\
Subtotal & 998 & 99.8 & 100.0 & \\
NA & 2 & 0.2 & & \\
Total & 1000 & 100.0 & & \\
\hline
\end{tabular}

Then, the possibility of women encountering difficulties reaching managerial and decision-making positions was investigated. As shown in Table 6 opinions differ since $49.3 \%$ consider that women face difficulties and $50.7 \%$ say that there are no such difficulties.

Table 6. Women and difficulties in managerial and decision-making positions.

\begin{tabular}{ccccc}
\hline & Frequency & Percentage & Valid & Cumulative Percentage \\
\hline no & 504 & 50.4 & 50.7 & 50.7 \\
yes & 491 & 49.1 & 49.3 & 100.0 \\
Subtotal & 995 & 99.5 & 100.0 & \\
NA & 5 & 0.5 & & \\
Total & 1000 & 100.0 & & \\
\hline
\end{tabular}

The main reasons that lead women to encounter difficulties in managerial or decision-making positions are shown in the graph below. As shown, the main reason is the stereotypes (24.9\%) still dominating the Greek society followed by the attitude of men $(8.7 \%)$.

Regarding the skills necessary for women's employability in the 21st century, the respondents indicated as crucial skills those related to ICT management, communication, problem solving, teamwork, and interpersonal skills. Respondents ranked in lowest positions business architecture, interpretation of numerical data, and operations planning skills (Figure 1). 


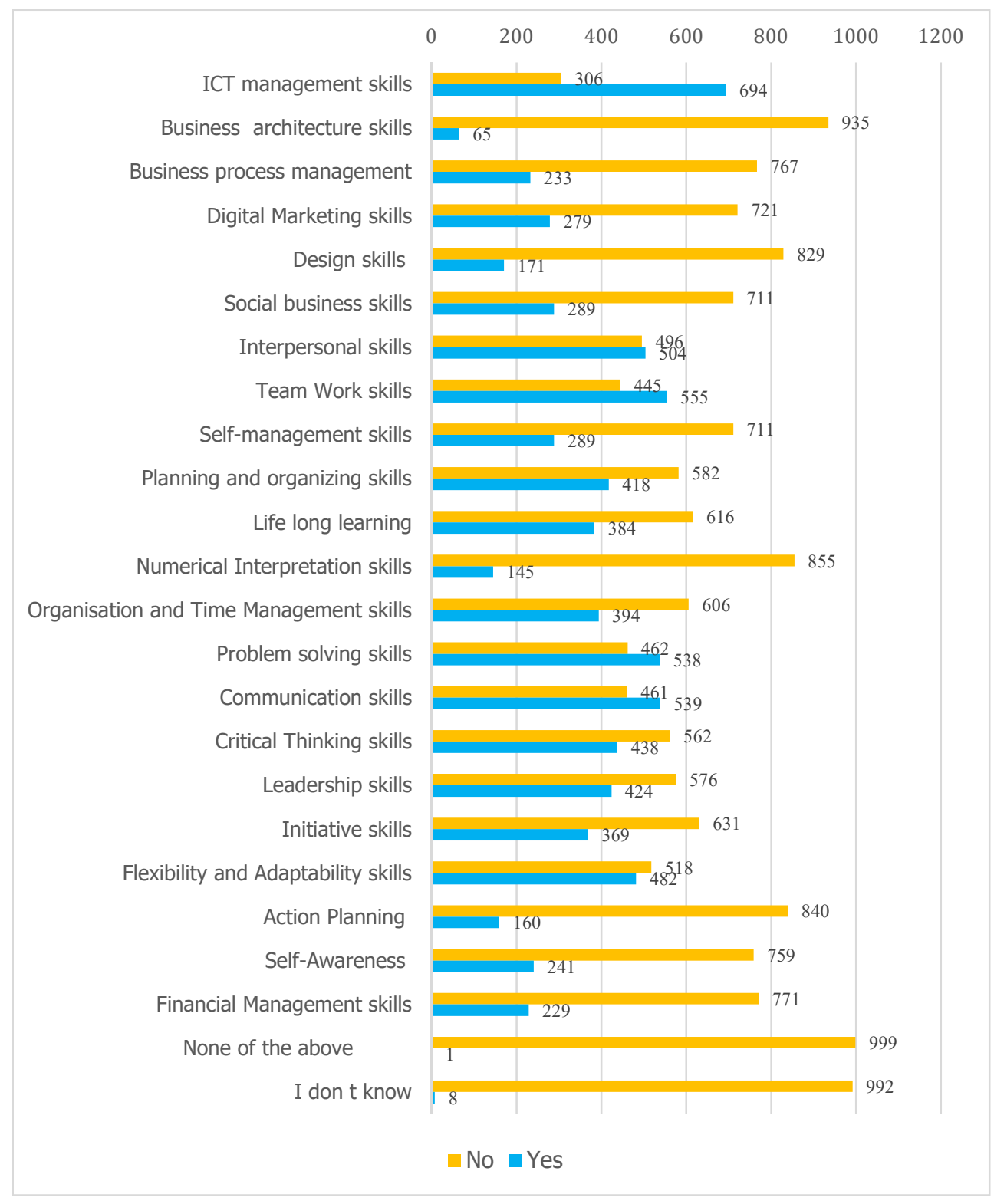

Figure 1. Frequency of skills necessary for women's employability in the 21st century.

\subsubsection{Women's Entrepreneurship in ICT Sector and Entrepreneurial Skills}

The next category of questions aimed to investigate women's entrepreneurship in the ICT sector. The first question was designed to assess women's ability in entrepreneurship compared with that of men. The vast majority of women respondents (91.4\%) saw no such distinction.

The second question was designed to explore whether the numbers of female entrepreneurs in sectors that require ICT skills are low compared with other sectors. As shown by the results, $76.8 \%$ of the respondents claim that the numbers of women entrepreneurs in areas that require ICT skills are limited.

Then the views of women were investigated, whether the sector of ICT-based entrepreneurship is one of the most crucial factors of success nowadays. $90.1 \%$ of the participating women agreed with this statement.

Figure 2 shows the skills that appear as most important for entrepreneurship nowadays. Innovation, vision/imagination, organizational skills, creativity, negotiation abilities, resourcefulness, and initiative were found to be the most important. 


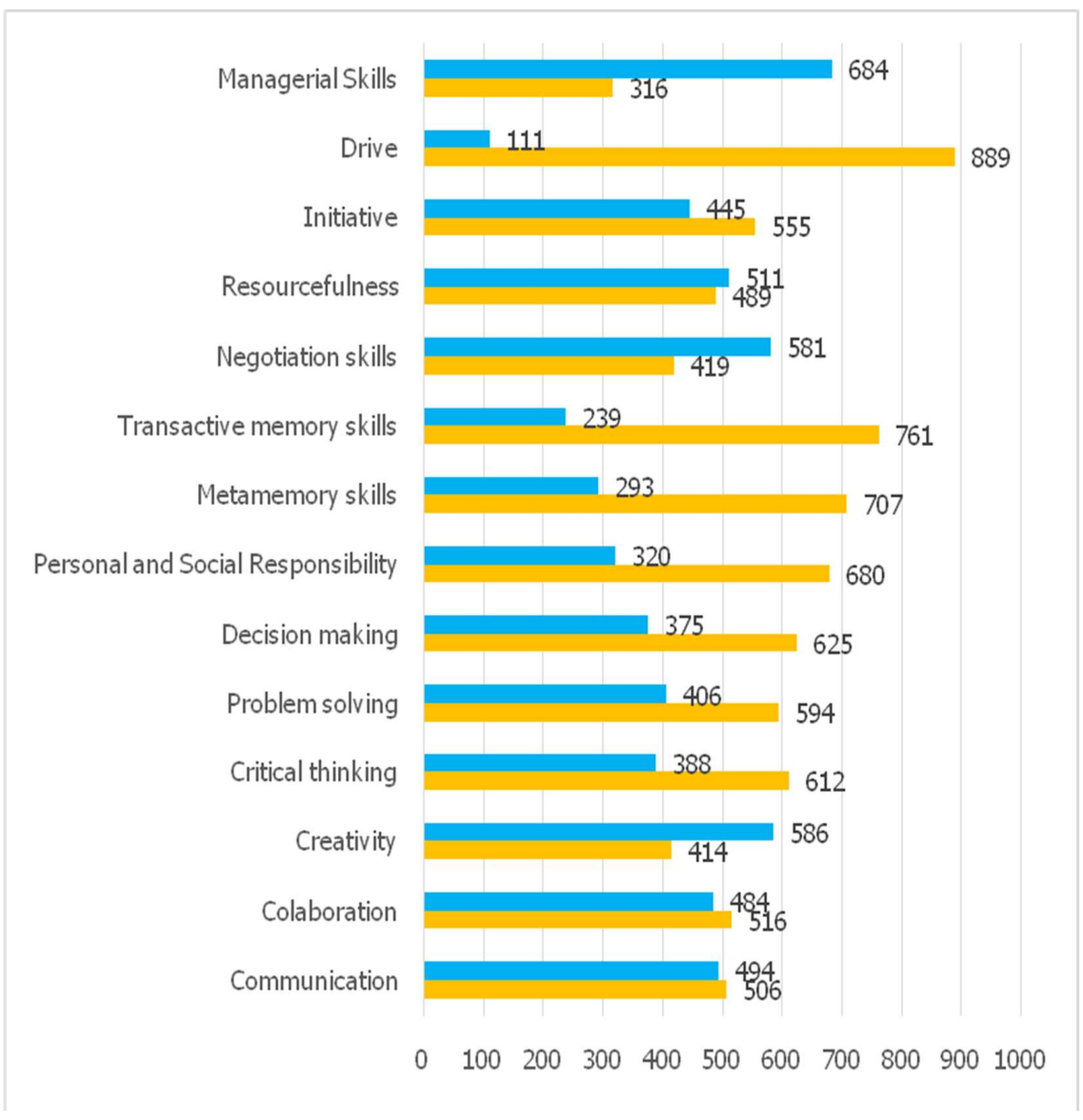

Figure 2. Which of these skills do you think are the most important for women entrepreneurs in the 21st century?

\subsubsection{Inductive Analysis}

The presentation of descriptive data of the survey is followed by the presentation of the inductive data analysis. For the implementation of the inductive analysis we used parametric criteria, and where the homogeneity control was statistically significant we used non-parametric criteria. Statistical analysis was performed with a confidence level of $95 \%$ and a $p$-value less than 0.05 was considered statistically significant. The bivariate analysis showed statistically significant differences in the assessment of the attitude of women towards computers and ICTs compared to men's, based on women's perception $(\mathrm{Q} 25)(\mathrm{F}(5,982)=3.01, p=0.010)$, the existence of the mismatches between e-skills supply and demand $(\mathrm{Q} 30)(\mathrm{F}(5,968)=2.94, p=0.012)$, the level of competence in ICT skills $(\mathrm{Q} 31)$ $(\mathrm{F}(5,982)=17.56, p=0.000)$ the willingness to expand their knowledge in ICT $(\mathrm{Q} 32)(\mathrm{F}(5,982)=2.56$, $p=0.025)$, the importance of ICT skills in their work $(\mathrm{Q} 33)(\mathrm{F}(5,982)=6.91, p=0.000)$, and the importance of social media in enterprising $(\mathrm{Q} 35)(\mathrm{F}(5,982)=6.60, p=0.000)$ in regard to the educational level (Figure 3).

Moreover, the bivariate analysis revealed statistically significant differences in the difficulty women face in managerial and decision-making positions $(\mathrm{Q} 10)(\mathrm{F}(4,994)=7.06, p=0.000)$, the assessment of women's entrepreneurial capacity compared to men's, based on women's perception $(\mathrm{Q} 14)(\mathrm{F}(4,991)=2.79, p=0.025)$, the equal motivation of men and women for ICT studies and careers $(\mathrm{Q} 21)(\mathrm{F}(4,994)=4.01, p=0.003)$ the existence of a gender gap in both computer professions and new professions linked to new communication technology $(\mathrm{Q} 22)(\mathrm{F}(4,992)=8.74, p=0.000)$, the under-representation of females in the ICT sector $(\mathrm{Q} 23)(\mathrm{F}(4,990)=2.68, p=0.031)$, the level of competence in ICT skills $(\mathrm{Q} 31)(\mathrm{F}(5,982)=3.90, p=0.004)$, the willingness to expand their knowledge 
in ICT $(\mathrm{Q} 32)(\mathrm{F}(4,990)=4.84, p=0.001)$, the influence of social media on the professional profile (Q34) $(\mathrm{F}(4,987)=3.24, p=0.012)$, and the significance of social media in business $(\mathrm{Q} 35)(\mathrm{F}(4,986)=3.80$, $p=0.005)$ related to age (Figure 4 ).

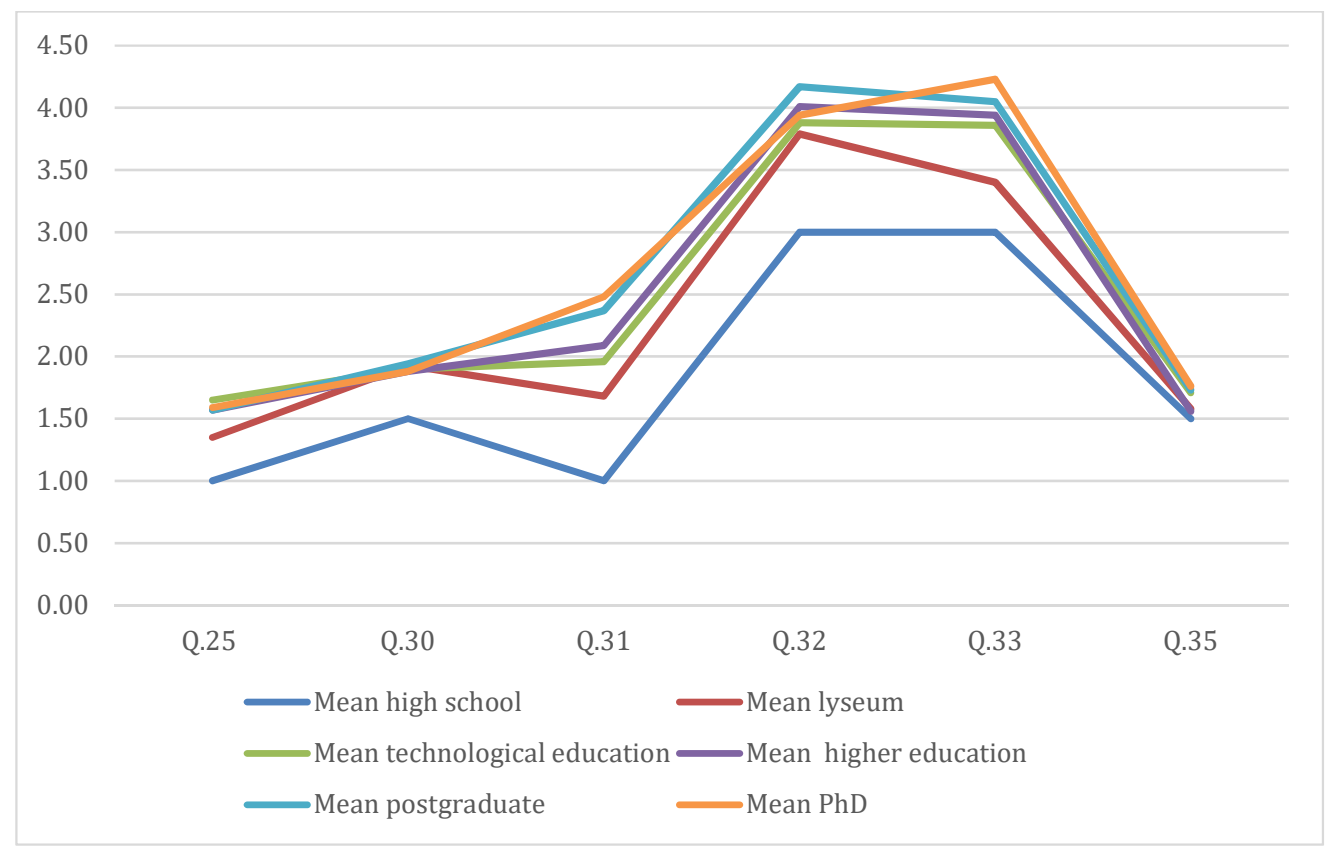

Figure 3. Statistically significant differences related to the level of education.

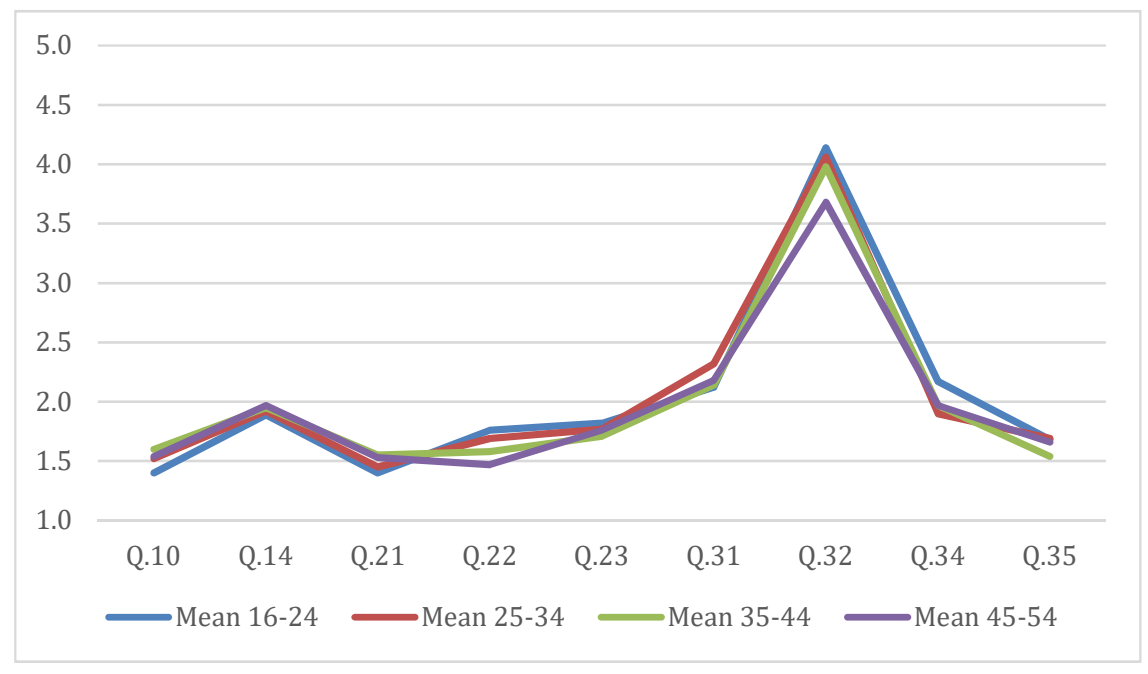

Figure 4. Statistically significant differences related to age.

Statistically significant differences also emerged in relation to marital status. The difficulty faced by women in managerial and decision-making positions $(\mathrm{Q} 10)(\mathrm{F}(4,993)=5.42, p=0.000)$, the significance of female digital entrepreneurship in the 21st century economy $(Q 16)(F(4,989)=4.45$, $p=0.000)$, the equal motivation of men and women for ICT studies and careers $(\mathrm{Q} 21)(\mathrm{F}(4,996)=3.92$, $p=0.004)$, the existence of a gender gap in both computer professions and new professions linked to new communication technology $(\mathrm{Q} 22)(\mathrm{F}(4,994)=3.33, p=0.010)$ showed statistically significant differences related to marital status (Figure 5). 


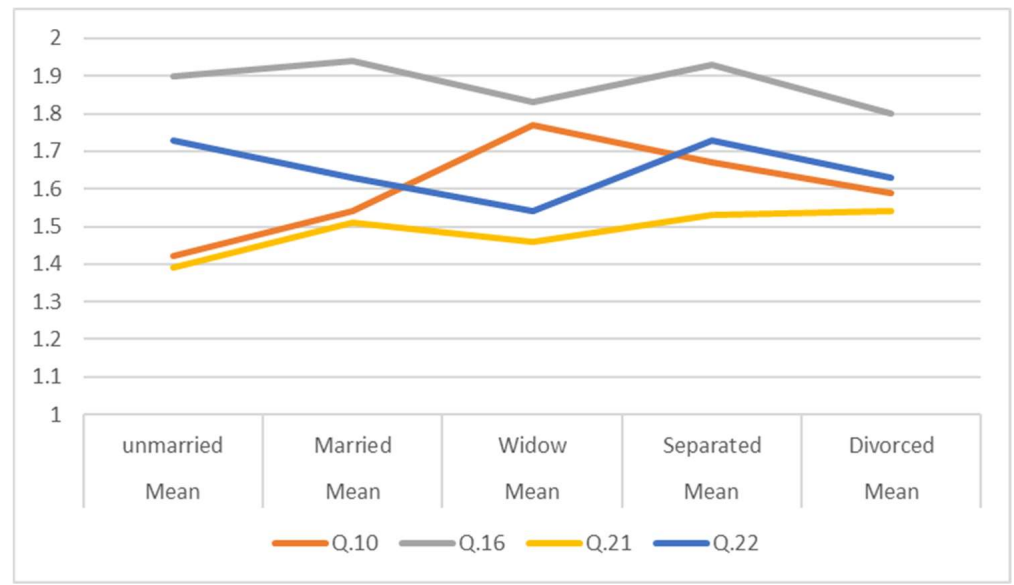

Figure 5. Statistically significant differences related to marital status.

Finally, statistically significant differences were noted in relation to the difficulty women face in managerial and decision-making positions $(\mathrm{Q} 10)(\mathrm{F}(4,994)=4.14, p=0.002)$, the existence of a gender gap in both computer professions and new professions linked to new communication technology (Q22) $(\mathrm{F}(4,995)=3.37, p=0.009)$, the level of competence in ICT skills $(\mathrm{Q} 31)(\mathrm{F}(4,922)=6.39, p=0.000)$, the willingness to expand their knowledge in ICT $(\mathrm{Q} 32)(\mathrm{F}(4,993)=3.95, p=0.003)$, and the importance of social media in business (Q35) $(\mathrm{F}(4,989)=4.64, p=0.001)$, related to the employment status of the participant in the survey (Figure 6).

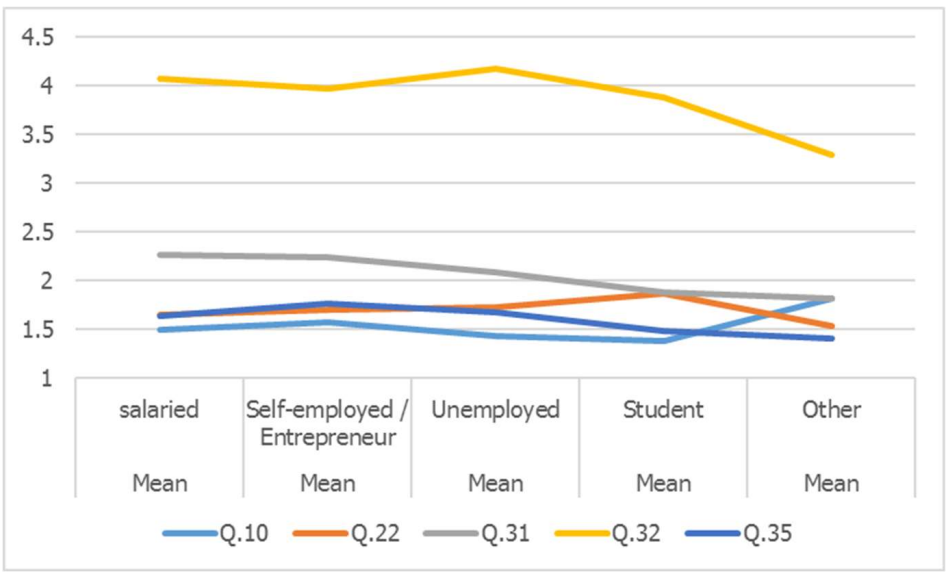

Figure 6. Statistically significant differences related to employment.

\subsection{Findings from Focus Group Interviews}

Results from the personal interviews revealed that women, at an overwhelming rate, feel that the sector of digital entrepreneurship is one of the most crucial factors of success nowadays, as well as that ICTs are extremely important in the workplace. From the interviews with the focus group it turned out that women believe that there are wide gaps and mismatches between supply and demand regarding ICT experts.

In addition, they feel that the percentage of female entrepreneurs in sectors with high demand of ICT skills is low. However, they do not believe that there is a significant distinction in entrepreneurship between men and women, and they attribute the low representation of women to perceptions deeply rooted in the past. A high percentage of women believe they are under-represented in the ICT industries, as well as that there is a gap based on gender in both the Information Technology professions and the new professions associated with new communication technologies. 
In their majority, women stated that they are aware of the importance of social media in the development of entrepreneurship, but they are not aware of ICT training. Most of them would be willing to participate in relevant educational actions and, although they consider their level to be moderate to satisfactory, they mainly refer to basic skills rather than more advanced IT applications.

Interviewees claimed that both public and private sector in Greece over the last five years are relatively adequate to digital skills, related to the use of the Internet and office tasks. The situation is different when we refer to more demanding tasks, where the participation of women is much lower. Employees who lacked in digital skills in previous years show significant improvement, however, they are limited in basic skills.

Most participants ignored the existence of the New Skills Agenda for Europe. They all agreed that there are no appropriate information channels in order for such initiatives to reach out to interested companies and their executives. Finally, interviewees highlighted as the most important employability skills "critical thinking", "creativity", "coordination", and "cognitive flexibility".

\section{Discussion}

The development of new technologies, such as ICT, and their convergence have changed the structure of work, the production process, as well as the goods produced and the services developed, creating new areas for employment. Although many reports have been published, it is not easy to ascertain whether women, in aggregate terms, have benefited from the information revolution or lost out. In a rapidly-changing environment, Information and Communication Technologies (ICT) could create great challenges for a smart, sustainable, and inclusive growth, both at the global and national levels. However, despite high levels of unemployment, shortages of e-skills continue to increase in all sectors and, even worse, a gender gap exists, excluding many women from both the sector and the labour market.

According to the findings the vast majority of survey participants remark that there is a significant mismatch between supply and demand in specific e-skills in Greece. Approximately $1 / 3$ of the participants in the field research and the focus group assess their competency level in ICT skills as "advanced", although almost $67 \%$ believe that ICT are very important for their work, and almost 1 in 2 that training in ICT will positively affect their professional status.

All three social research tools, which have been used, indicate that:

- Important gender gaps exist in entrepreneurship since men are three times more likely to own a business with employees than women.

- Cultural norms, stereotypes, and lack of role models prevent women from fully exploiting their potential, making women less interested in an entrepreneurial career and less confident in their capacities as entrepreneurs.

- Cultural norms, stereotypes, and lack of role models are also responsible for the struggling feeling of a glass ceiling often experienced by employed women.

- Economic barriers generate differences in business ownership rates and the entrepreneurial "success" of women and men.

- The low number of female graduates in scientific fields, as well as the limited number of women in executive positions, generate human capital and networking disadvantages for women in business.

- Female entrepreneurship could benefit from technological advances and, especially, digital entrepreneurship

\section{Conclusions}

Consequently, a number of actions and initiatives are recommended in order to enhance, promote, and support women's active participation as entrepreneurs and employees in the ICT sector, as well as in the other sectors of the economy, by exploiting ICT opportunities. The main challenges that will 
activate women in the targeted level of training, selection, and participation in entrepreneurship and employment with a focus on ICT should include:

Actions that can benefit the participation of women in entrepreneurship, developing a common definition and understanding of what digital skills and competences are, improving the understanding and definition of digital skills needs, upgrading the digital skills of the labour force with a focus on professional-related digital skills, overcoming the obstacles and/or limitations some people face to obtaining digital skills-including lack of interest, awareness, resources and/or knowledge, as well as fear of technology—and, finally, providing relevant digital skills training opportunities for all.

Actions that will enhance the role of women in the field of technology and STEM education, either as an employee or as an entrepreneur, making the ICT profession more attractive as a career choice, with a focus on encouraging more women to participate, increasing the number of young people trained for ICT professions (ICT graduates and conversions to ICT), as well as ensuring certification and standardization.

Training actions to support the entry of women into the labour market on equal terms regarding ICT skills and competences needed as, for example, to provide the adequate ICT environment where teaching and training will be in close relation with the labour market. Up-skilling of digital skills should become a target for the educational and Vocational Education and Training (VET) curricula, while all the changes should be aligned with a regional approach with respect to future skill needs.

Especially for women aspiring to become entrepreneurs, specific skills are required which will enable them to promote their products or services online, to collect customer insight, and target specific audiences through the use of social media. Specifically, a good practice could be the formation of a network of professional women, acting as mentors, in order to help women who want to start a business, pursue a professional career, or are unemployed, to reach their full potential. Workshops, seminars, and summer camps could also be utilized as knowledge transfer methods.

Future research should aim to investigate new techniques for promoting female entrepreneurship, as well as female employability, highlighting the strategic technology trends. At the same time, such research should be conducted with the aim of integrating marginalized social groups into the digital labour market.

Author Contributions: All authors participated in research development and dissemination of research results.

Acknowledgments: This paper was supported by the European Economic Area (EEA: http:/ /eeagrants.org/) Project entitled "e-Women: Innovation and Employability for Women".

Conflicts of Interest: The authors declare no conflicts of interest.

\section{References}

1. Estrin, S.; Mickiewicz, T. Institutions and female entrepreneurship. Small Bus. Econ. 2011, 37, 397. [CrossRef]

2. Hampton, A.; McGowan, P.; Cooper, S. Developing quality in female high-technology entrepreneurs' networks. Int. J. Entrep. Behav. Res. 2011, 17, 588-606. [CrossRef]

3. Yetim, N. Social capital in female entrepreneurship. Int. Sociol. 2008, 23, 864-885. [CrossRef]

4. Kobeissi, N. Gender factors and female entrepreneurship: International evidence and policy implications. J. Int. Entrep. 2010, 8, 1-35. [CrossRef]

5. European Commission. Women Active in ICT Sector; FINAL REPORT, A Study Prepared for the European Commission, DG Communications Networks, Content \& Technology: Brussel, Belgique, 2013.

6. Ranga, M.; Etzkowitz, H. Athena in the world of techne: The gender dimension of technology, innovation and entrepreneurship. J. Technol. Manag. Innov. 2010, 5, 1-12. [CrossRef]

7. Women Entrepreneurs in Europe; DG Enterprise and Industry of the European Commission: Amsterdam, The Netherlands, 2014.

8. Van der Zwan, P.; Verheul, I.; Thurik, A.R. The entrepreneurial ladder, gender, and regional development. Small Bus. Econ. 2012, 39, 627-643. [CrossRef]

9. Bruni, A.; Gherardi, S.; Poggio, B. Gender and Entrepreneurship: An Ethnographic Approach; Routledge: Oxfordshire, UK, 2014. 
10. Huarng, K.H.; Ribeiro-Soriano, D.E. Developmental management: Theories, methods, and applications in entrepreneurship, innovation, and sensemaking. J. Bus. Res. 2014, 67, 657-662. [CrossRef]

11. Vossenberg, S. Women Entrepreneurship Promotion in Developing Countries: What explains the gender gap in entrepreneurship and how to close it. Maastricht Sch. Manag. Work. Paper Ser. 2013, 8, 1-27.

12. Herman, C. Returning to STEM: Gendered factors affecting employability for mature women students. J. Educ. Work 2015, 28, 571-591. [CrossRef]

13. Ghavifekr, S.; Jani, R.B.; Kenayathulla, H.B.B. Gender and employability in higher learning institutions in malaysia: Implication for leadership and policy. PEOPLE Int. J. Soc. Sci. 2016, 2, 455-468. [CrossRef]

14. Modesto, T.S.; Ongori, H.; Agolla, J.E.; Agolla, J.E.; Van Lill, J.B.; Sechele-Mosimanegape, P.; Gumbo, C. Women in management: The case for Botswana. Eur. J. Res. Reflect. Manag. Sci. 2016, 4, 2.

15. Yun, J.J. How do we conquer the growth limits of capitalism? Schumpeterian Dynamics of Open Innovation. J. Open Innov. Technol. Market Complex. 2015, 1, 17. [CrossRef]

16. Yun, J.J.; Won, D.; Hwang, B.; Kang, J.; Kim, D. Analysing and simulating the effects of open innovation policies: Application of the results to Cambodia. Sci. Public Policy 2015, 42, 743-760. [CrossRef]

17. Yun, J.J.; Won, D.; Park, K. Dynamics from open innovation to evolutionary change. J. Open Innov. Technol. Mark. Complex. 2016, 2, 7. [CrossRef]

18. Coccoli, M.; Guercio, A.; Maresca, P.; Stanganelli, L. Smarter universities: A vision for the fast changing digital era. J. Vis. Lang. Comput. 2014, 25, 1003-1011. [CrossRef]

19. Dunleavy, P.; Margetts, H.Z. The Second Wave of Digital Era Governance; American Political Science Association: Oxford, UK, 2010.

20. Ziyae, B.; Sajadi, S.M.; Mobaraki, M.H. The deployment and internationalization speed of e-business in the digital entrepreneurship era. J. Glob. Entrep. Res. 2014, 4, 15. [CrossRef]

21. Dobón, S.R.; Soriano, D.R. Exploring alternative approaches in service industries: The role of entrepreneurship. Serv. Ind. J. 2008, 28, 877-882. [CrossRef]

22. Vliamos, S.J.; Tzeremes, N.G. Factors influencing entrepreneurial process and firm start-ups: Evidence from central Greece. J. Knowl. Econ. 2012, 3, 250-264. [CrossRef]

23. Gidarakou, I. Women's entrepreneurship in rural Greece. Int. J. Bus. Manag. 2015, 10, 129. [CrossRef]

24. Sarri, K.; Trihopoulou, A. Female entrepreneurs' personal characteristics and motivation: A review of the Greek situation. Women Manag. Rev. 2005, 20, 24-36. [CrossRef]

25. European Commission. Digital Economy and Society Index. 2017. Available online: https://ec.europa.eu/ digital-single-market/en/desi (accessed on 7 May 2018).

26. Maclean, G.; Marks, A.; Chillas, S. Women, Work and Technology: Examining the Under-Representation of Women in ICT; How New Technologies Revolutionise Work; Palgrave Macmillan: Basingstoke, UK, 2017; pp. 177-194.

27. Armstrong, J. "Is IT Unfriendly to Women?" Tech Republic, 25 June 2005. Available online: http: / / techrepublic.com.com/5102-10878-5753934.html (accessed on 14 December 2017).

28. Woodfield, R. Women and information systems development: Not just a pretty (inter)face. Inf. Technol. People 2002, 15, 119-138. [CrossRef]

29. Yeo, B.; Grant, D. ICT Impact on Productivity: Exploring Implications of Females in the Workforce; pre-European Conference on Information Systems (ECIS): Istanbul, Turkey, 2016.

30. Leiter, M.P.; Maslach, C. Areas of worklife: A structured approach to organizational predictors of job burnout. In Emotional and Physiological Processes and Positive Intervention Strategies; Emerald Group Publishing Limited: Bingley, UK, 2003; pp. 91-134.

31. Trauth, E.M.; Howcroft, D. Critical empirical research in IS: An example of gender and the IT workforce. Inf. Technol. People 2006, 19, 272-292. [CrossRef]

32. Timms, C.; Lankshear, C.; Anderson, N.; Courtney, L. Riding a hydra: Women ICT professionals' perceptions of working in the Australian ICT industry. Inf. Technol. People 2008, 21, 155-177. [CrossRef]

33. Morris, D.; Trushell, J. Computer programming, ICT and gender in the classroom: A male-dominated domain or a female preserve? Res. Teach. Educ. 2014, 4, 4-9. Available online: http://hdl.handle.net/10552/3630 (accessed on 10 January 2018).

34. Tondeur, J.; Van de Velde, S.; Vermeersch, H.; Van Houtte, M. Gender Differences in the ICT Profile of University Students: A Quantitative Analysis. J. Divers. Gend. Stud. 2016, 3, 57-77. [CrossRef] 
35. Bebetsos, E.; Antoniou, P. Gender differences on attitudes, computer use and physical activity among Greek university students. TOJET Turk. Online J. Educ. Technol. 2009, 8, 63-68.

36. Aesaert, K.; Van Braak, J. Gender and socioeconomic related differences in performance based ICT competences. Comput. Educ. 2015, 84, 8-25. [CrossRef]

37. Marcoulides, G.A.; Wang, X.B. A cross-cultural comparison of computer anxiety in college students. J. Educ. Comput. Res. 1990, 6, 251-263. [CrossRef]

38. Torkzadeh, G.; Van Dyke, T.P. Effects of training on Internet self-efficacy and computer user attitudes. Comput. Hum. Behav. 2002, 18, 479-494. [CrossRef]

39. OECD. PISA 2012 Database; OECD: Paris, France, 2015.

40. Kanny, M.A.; Sax, L.J.; Riggers-Piehl, T.A. Investigating forty years of STEM research: How explanations for the gender gap have evolved over time. J. Women Minor. Sci. Eng. 2014, 20. [CrossRef]

41. Diekman, A.B.; Clark, E.K.; Johnston, A.M.; Brown, E.R.; Steinberg, M. Malleability in communal goals and beliefs influences attraction to stem careers: Evidence for a goal congruity perspective. J. Personal. Soc. Psychol. 2011, 101, 902. Available online: http:/ / psycnet.apa.org/doi/10.1037/a0025199 (accessed on 10 January 2018). [CrossRef] [PubMed]

42. Nosek, B.A.; Smyth, F.L.; Sriram, N.; Lindner, N.M.; Devos, T.; Ayala, A.; Bar-Anan, Y.; Bergh, R.; Cai, H.; Gonsalkorale, K.; et al. National differences in gender-science stereotypes predict national sex differences in science and math achievement. Proc. Natl. Acad. Sci. USA 2009, 106, 10593-10597. Available online: http:/ / www.pnas.orgcgidoi10.1073pnas.0809921106\%20pna/ (accessed on 17 December 2017). [CrossRef] [PubMed]

43. Lindberg, S.M.; Hyde, J.S.; Petersen, J.L.; Linn, M.C. New trends in gender and mathematics performance: A meta-analysis. Psychol. Bull. 2010, 136, 1123. Available online: http://psycnet.apa.org/doi/10.1037/ a0021276 (accessed on 15 January 2018). [CrossRef] [PubMed]

44. Liben, L.S. The STEM gender gap: The case for spatial interventions. Int. J. Gend. Sci. Technol. 2015, 7, 133-150. [CrossRef]

45. Krämer, N.C.; Karacora, B.; Lucas, G.; Dehghani, M.; Rüther, G.; Gratch, J. Closing the gender gap in STEM with friendly male instructors? On the effects of rapport behavior and gender of a virtual agent in an instructional interaction. Comput. Educ. 2016, 99, 1-13. [CrossRef]

46. Johnson, R.D. Gender differences in e-learning: Communication, social presence, and learning outcomes. J. Organ. End User Comput. (JOEUC) 2011, 23, 79-94. [CrossRef]

47. Liaw, S.S.; Huang, H.M. A Study of Investigating Learners' Attitudes Toward e-Learning. 2011. Available online: https:/ / pdfs.semanticscholar.org/798b/880bb4e1a5a2dadcea73f828178bf28cf313.pdf (accessed on 7 May 2018).

48. Egbo, O.P.; Okoyeuzu, C.R.; Ifeanacho, I.C.; Onwumere, J.U. Gender perception and attitude towards e-learning: A case of business students, University of Nigeria. Int. J. Comput. Appl. 2011, 1, 135-148.

49. Suri, G.; Sharma, S. The impact of gender on attitude towards computer technology and e-learning: An exploratory study of Punjab University, India. Int. J. Eng. Res. 2013, 2, 132-136.

50. Zabadi, A.M.; Al-Alawi, A.H. University Students' Attitudes towards E-Learning: University of Business \& Technology (UBT)-Saudi Arabia-Jeddah: A Case Study. Int. J. Bus. Manag. 2016, 11, 286. [CrossRef]

51. Pantazis, C. Maximizing e-learning to train the 21st century workforce. Public Pers. Manag. 2002, 31, $21-26$. [CrossRef]

52. Goldman, M. Perspectives on telementoring and mentor center. Natl. Sch. Netw. Telementoring Mentor Center 1997. Available online: http:/ /nsn.bbn.com/telementorwrkshp/goldman.html (accessed on 19 January 2018).

53. Headlam-Wells, J.; Gosland, J.; Craig, J. Beyond the organisation: The design and management of E-mentoring systems. Int. J. Inf. Manag. 2006, 26, 372-385. [CrossRef]

(C) 2018 by the authors. Licensee MDPI, Basel, Switzerland. This article is an open access article distributed under the terms and conditions of the Creative Commons Attribution (CC BY) license (http://creativecommons.org/licenses/by/4.0/). 